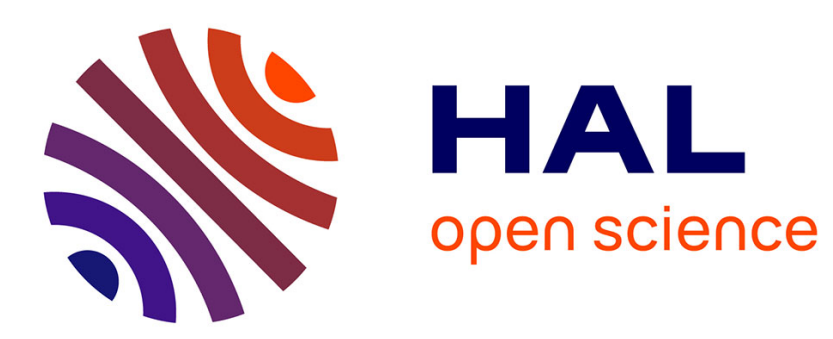

\title{
Photothermal and optical absorption studies of electrodeposited polyaniline
}

\author{
T. Toyoda, H. Nakamura
}

\section{To cite this version:}

T. Toyoda, H. Nakamura. Photothermal and optical absorption studies of electrodeposited polyaniline. Journal de Physique IV Proceedings, 1994, 04 (C7), pp.C7-183-C7-186. 10.1051/jp4:1994744 . jpa00253273

\section{HAL Id: jpa-00253273 https://hal.science/jpa-00253273}

Submitted on 1 Jan 1994

HAL is a multi-disciplinary open access archive for the deposit and dissemination of scientific research documents, whether they are published or not. The documents may come from teaching and research institutions in France or abroad, or from public or private research centers.
L'archive ouverte pluridisciplinaire HAL, est destinée au dépôt et à la diffusion de documents scientifiques de niveau recherche, publiés ou non, émanant des établissements d'enseignement et de recherche français ou étrangers, des laboratoires publics ou privés. 


\title{
Photothermal and optical absorption studies of electrodeposited polyaniline
}

T. Toyoda and H. Nakamura

Department of Applied Physics and Chemistry, The University of Electro-Communications, 1-5-1 Chofugaoka, Chofu, Tokyo 182, Japan

\begin{abstract}
Photothermal spectroscopy using thermistor is applied to study the heat generation by nonradiative processes in electrodeposited polyaniline together with the optical absorption. Although the optical absorption spectra showed several peaks, photothermal ones showed monotonous changes against photon energy. It shows that the increase of signal intensity of heat generation is difrent from that of optical absorption.
\end{abstract}

\section{INTRODUCTION}

Polyaniline is a very attractive conducting polymer because it exhibits good stability and the redox mechanisms involve the exchange of protons and electrons[1]. Also, it has attracted much attention because of fundamental interest and possible applications such as batteries, electrochromic displays and others as we11[2,3]. However, the recent 1 iterature on this material is not clear and subject to controversy. Although several investigations have been carried out on the optical absorption [1,4], there are few investigations on the photothermal spectroscopy of polyaniline. In general, photothermal spectroscopy will offer useful information on electron-phonon interactions. We present here the experimental results of photon energy dependence of the direct detection of temperature changes resulting from nonradiative processes in electrodeposited polyaniline together with optical absorption using a simple photothermal spectroscopy apparatus (PTS) by Brilmyer et al[5].

\section{EXPERIMENTAL}

Polyaniline films were deposited on IT0 glasses by constant-potential electrolysis (+0.7 V versus Ag/AgCl electrode (RE)) in aqueous solution containing $0.5 \mathrm{M}$ aniline in $1.0 \mathrm{M} \mathrm{HCl}(1-5 \mathrm{~min}$.$) . NaOH was added in order$ 
to investigate the pH dependence of PTS and optical absorption on polymerization. Then the potentiostatic oxidation was carried out at t0.6 $V$ versus RE (2.5 min.) in $0.1 \mathrm{M} \mathrm{HCl}$ following the reduction at $-0.2 \mathrm{~V}$ versus $\operatorname{RE~(2.5~min.).~The~films~exhibit~a~granular~morphology~except~} 1$ min. polymerization sample which exhibits a fibril morphology and the thickness is approximately $0.5 \mu \mathrm{m}$ for all the samples. The cell for PTS is described elsewhere[5-7]. PTS measurements were carried out by two thermistors in a differential arrangement ( one for the sample and the other for reference) which was compensated for changes in ambient temperature. The thermistor has a nominal resistance of $12 \mathrm{k} \Omega$. and a sensitivity of $480 \Omega / K$ at $20^{\circ} \mathrm{C}$. The signals were measured as the difference of resistance between working and reference thermistors, since temperature changes in the sample resulted in an unbalance of a Wheatstone bridge powered by a dc $1.0 \mathrm{~V}$. The $1 \mathrm{ight}$ source was a 500 whort arc xenon lamp. The light beam was focused on the sample through a monochromator with light impinging on an area of $0.16 \mathrm{~cm}^{3}$. Neither thermistor was irradiated by the exciting beam during the experiment. PTS measurements were carried out at room temperature over the wavelength range from 320 nm to $900 \mathrm{~nm}$. The PTS signal intensity was always divided by the 1 ight intensity measured by PTS of carbon for normalization. The optical absorption and reflection were measured by conventional methods.

\section{RESULTS AND DISCUSSION}

Fig. 1 shows the PTS signal intensities of electrodeposited polyline films without potentiostatic oxidation in $\mathrm{pH}=1.0$ for different polymerization times as functions of photon energy. They show monotonous changes and the peaks at $4.0 \mathrm{eV}$. The tota1 rates of optical energy absorption, $1-\mathrm{T}-\mathrm{R}$ (T: transmittance; R: reflectance), in polyaniline films without potentiostatic oxidation are plotted in Fig.2. Fig.2 shows that there are minima at $2.5 \mathrm{eV}$ photon energy for different polymerization time. In order to compare the increases and changes of both PTS and $1-T-R$. PTS signals were divided by $1-T-R$ $(\operatorname{PTS} /(1-\mathrm{T}-\mathrm{R}))$. Fig. 3 shows the

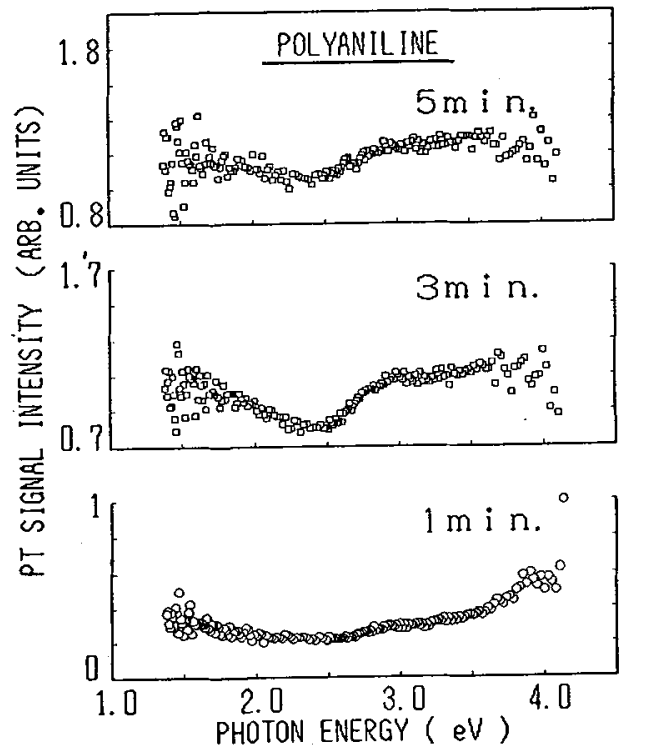

Fig.1. Photon energy dependence of PT $S$ of polyaniline films without oxidation for different polymerization times $(\mathrm{pH}=1,0)$. 


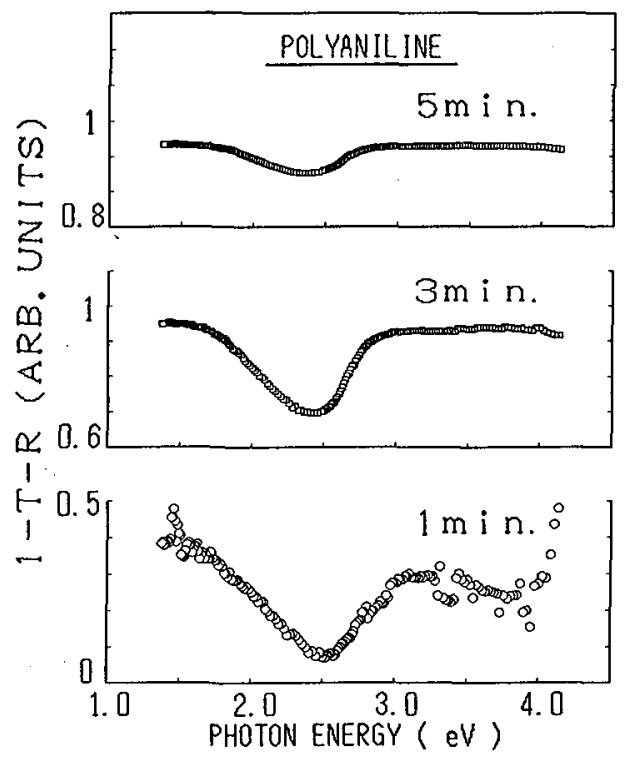

Fig. 2. Photon energy dependence of $1-T-R$ of polyaniline films without oxidation for different polymerization times $(\mathrm{pH}=1.0)$.

photon energy dependence of the PTS/ (1-T-R) for polyaniline films without potentiostatic oxidation for different polymerization times. The result indicates that the increases and changes of PTS are identical with those of the total rate of optical energy absorption except the case for $1 \mathrm{~min}$. polymerization. Fig. 4 shows the PTS signal intensity of electrodeposited polyaniline films with oxidation as a function of photon energy for different pH values. They show monotonous changes and the peaks at $4.0 \mathrm{eV}$. The slope of the decreasing of the PTS signal between $1.5 \mathrm{eV}$ and $3.0 \mathrm{eV}$ is depend on the pH values. $1-T-R$ of polyaniline films are plotted in Fig.5. Fig. 5 shows that there are two peaks $(\sim 2.1 \mathrm{eV}, \sim$

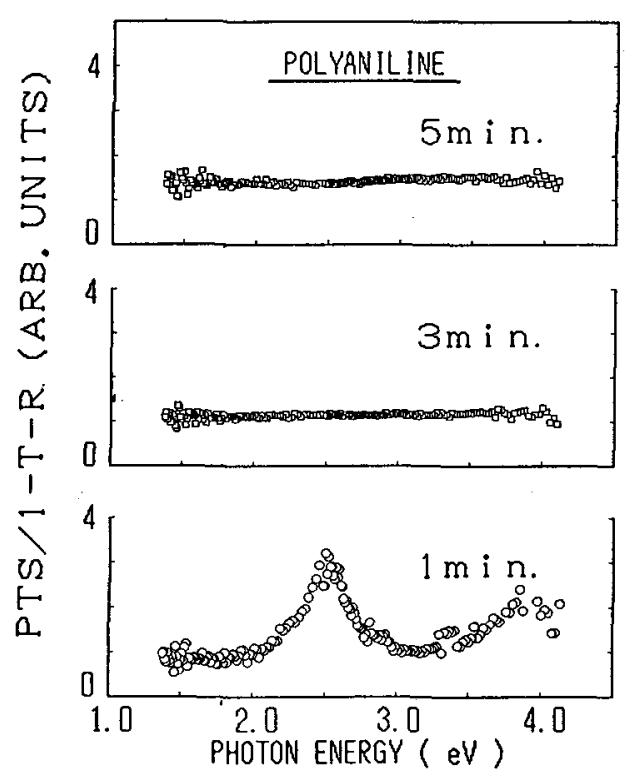

Fig. 3. Photon energy dependence of PTS/ (1-T-R) of polyaniline films without oxidation for different polymerizaion times $(\mathrm{pH}=1.0)$.

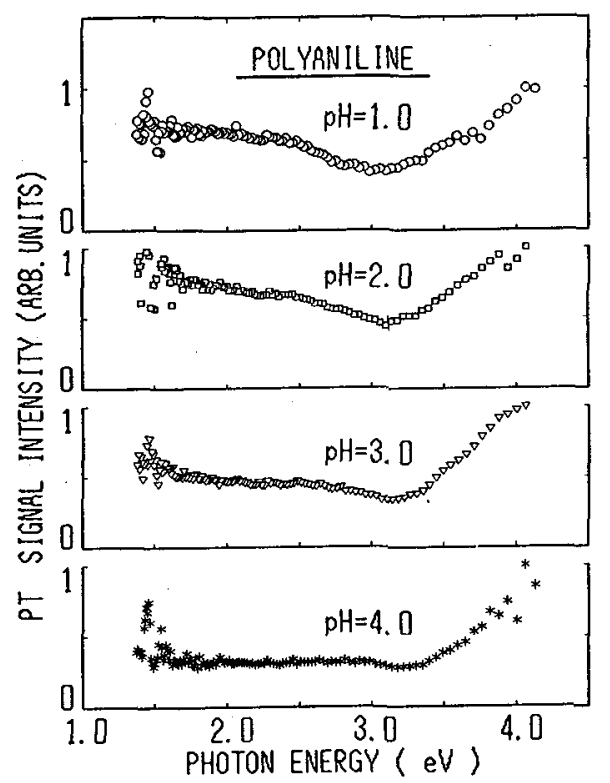

Fig. 4. Photon energy dependence of PTS of polyaniline films with oxidation for different $p H$ values. 


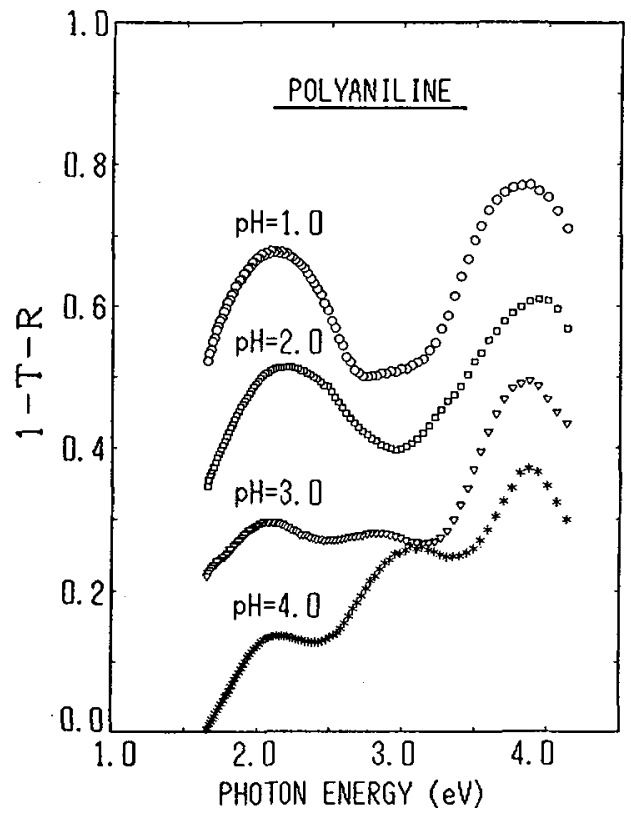

Fig. 5.Photon energy dependence of $1-T-R$ of polyaniline films with oxidation for different $\mathrm{pH}$ values.

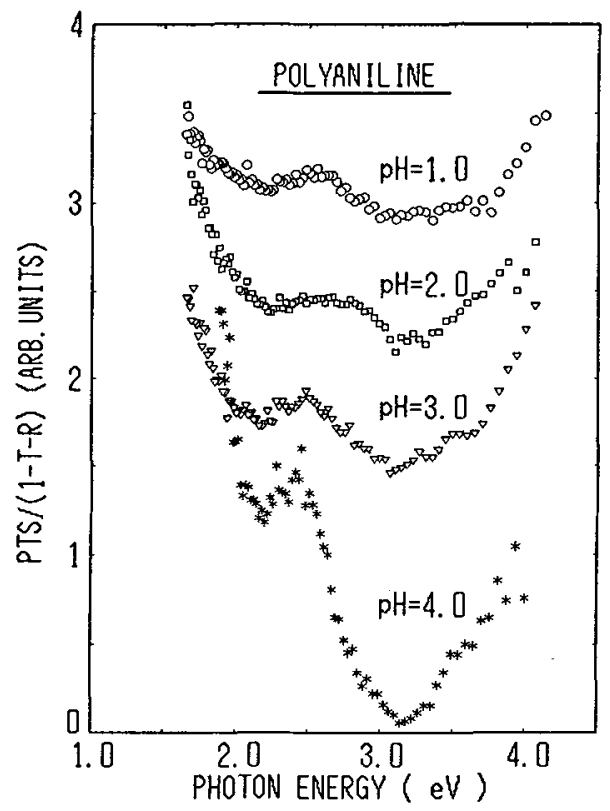

Fig. 6. Photon energy dependence of PTS/(1-T-R) of polyaniline films with oxidation for different $\mathrm{pH}$ values.

$4.0 \mathrm{eV})$ and another peak $(\sim 3.0 \mathrm{eV})$ for $\mathrm{pH}=3.0$ and 4.0 . The spectra of 1-T-R are different from those of the PTS. Fig.6 shows the photon energy dependence of the PTS/(1-T-R) for polyaniline films with oxidation. The result indicates that the increases and changes of the PTS are different from those of the total rate of optical energy absorption, $1-T-R$, and depend on the pH values. Fig.6 suggests that there is a different yield of thermal deactivation and it is related to the polymerization processes of electrodeposited polyaniline with oxidation.

\section{REFERENCES}

[1] Genies E.M. and Lapkowski M., J.Electroanal. Chem.220(1987)67-82.

[2] Nakajima T. and Kawagoe T.. Synth.Metals 28(1989)C629-C638.

[3] Kobayashi T., Yoneyama H. and Tamura H., J.Electroanal.Chem.161(1984) $419-423$.

[4] Sariciftci N.S.,Bartonek M..Kuzmany H.. Neugebauer H. and Neckel A.. Synth. Metals 29(1989)E193-E202.

[5]Brilmyer G.H.,Fujishima A. Santhanam K.S.V. and Bard A.J., Ana1.Chem. 49(1977)2057-2062.

[6] Fujishima A., Masuda H. and Honda K., Anal. Chem. 52(1980)682-685.

[7]Brilmyer G.H. and Bard A.J., Ana1. Chem.52(1980)685-691. 